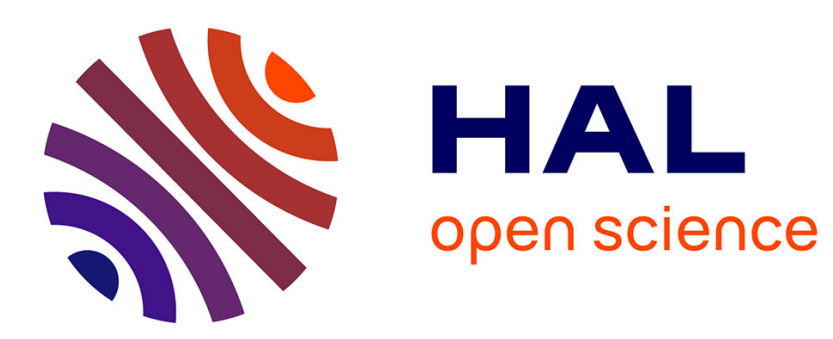

\title{
Justice in development? An analysis of water interventions in the rural South
}

Jean-Philippe Venot, Floriane Clement

\section{To cite this version:}

Jean-Philippe Venot, Floriane Clement. Justice in development? An analysis of water interventions in the rural South. Natural Resources Forum, 2013, 37 (1), pp.19-30. 10.1111/1477-8947.12002 . hal-02643711

\section{HAL Id: hal-02643711 \\ https://hal.inrae.fr/hal-02643711}

Submitted on 28 May 2020

HAL is a multi-disciplinary open access archive for the deposit and dissemination of scientific research documents, whether they are published or not. The documents may come from teaching and research institutions in France or abroad, or from public or private research centers.
L'archive ouverte pluridisciplinaire HAL, est destinée au dépôt et à la diffusion de documents scientifiques de niveau recherche, publiés ou non, émanant des établissements d'enseignement et de recherche français ou étrangers, des laboratoires publics ou privés. 


\title{
Justice in development? An analysis of water interventions in the rural South
}

\author{
Jean-Philippe Venot and Floriane Clement
}

\begin{abstract}
This paper explores a fruitful convergence between the distributive and procedural dimensions of environmental justice theory and current debates in the field of development studies over capitals and capabilities, institutions, and discourse formation to shed new light on natural resource management projects in the developing world. Specifically, we document the planning and implementation of two types of water interventions in two contrasting regions: watershed development programmes in northeast India and small reservoirs in sub-Saharan West Africa. We find that there is a contradiction between the inherently political nature of water interventions and the fact that such projects remain grounded in apolitical, technical and managerial narratives. In contrast to the new semantic of development, this depoliticization results in the near absence of attention paid to procedural (participation and empowerment) and distributive (equity) justice concerns and in local actors having to revert to covert ways to achieve their ends. A constructive dialogue between development studies and environmental justice scholars can offer a fresh look on the society-environment nexus in the developing world.
\end{abstract}

Keywords: Environmental justice; governance; discourse; water resources; India; sub-Saharan Africa.

\section{Introduction}

In 2007, the World Development Report heralded the "comeback" of agriculture after a 25 -year hiatus on the development agenda. The report highlighted two regional challenges - improving agricultural productivity in subSaharan Africa and enhancing diversification in Asia - and a global challenge - a better stewardship of natural resources, including water.

As an upshot, new water projects and reforms continue to emerge on the grounds that they contribute to poverty alleviation and enhance rural livelihoods by improving food production and agricultural productivity. Yet various studies have argued that water development projects can have negative social and environmental externalities. In particular, water projects have often induced changes in the patterns of access and control over natural resources at the local or macro level, often exacerbating existing inequities. So-called participatory approaches, whereby greater power of decision-making is given to communities, have been advocated as a tool to reach more equitable and just

Jean-Philippe Venot is at the Irrigation and Water Engineering Group, Environmental Sciences Department, Wageningen University, Wageningen, The Netherlands. E-mail: jean-philippe.venot@wur.nl Floriane Clement is at the International Water Management Institute, Kathmandu, Nepal. E-mail: f.clement@cgiar.org outcomes. However, "participation" and "empowerment" have de facto been depoliticized in mainstream development discourses (Cornwall and Brock, 2005) and participatory approaches in the field of natural resource management have often reinforced rather than challenged power imbalances (Blaikie, 2006).

This, we argue, is largely because projects and reforms that promote participation are framed in technicomanagerial terms and tend to replicate a linear model of development and societal change where assembling the conditions for "success" would allow circumventing the causes for "failure". But success and failure remain mostly evaluated according to predefined objectives and targets, with little attention given to the complex processes driving project design, implementation and, ultimately, outcomes. This paper aims at going beyond this linear vision of development by looking at the unintended effects of development interventions. It does so by critically engaging with the pluralistic notion of environmental justice, which provides a vocabulary for political action and a policy principle that no public action will disproportionately disadvantage any particular social group (Agyeman and Evans, 2004), but is also an analytical tool that sheds new light on questions of equity and participation in the political process (Schlosberg, 2004).

Two main reasons prompted us to engage in a dialogue between development studies and environmental justice 
theory. First, tools from development studies can expand the power of environmental justice as an analytical tool. Second, environmental justice movements have long questioned dominant development paradigms (Schlosberg, 2004). This latter notion offers a vocabulary for political action and a policy principle in support of lessons from development studies that have yet to permeate mainstream development agencies and practices.

There has been little critical engagement with the relevance, scope and limits of environmental justice as an analytical tool to understand broader development processes. Conversely, the development literature seldom engages with the notion of justice. This paper contributes to filling these gaps through a comparative case study of the planning and implementation of water interventions in two contrasting regions: northeast India and sub-Saharan West Africa. Though designed independently (see Clement et al., 2011; Venot et al., 2012; for detailed accounts), the two studies investigate the discursive, institutional and political dimensions of water interventions - three explanatory variables that have long been the object of critical development studies (see for instance, Lund, 2010).

\section{Framing environmental justice in the context of development}

\subsection{Multiple environmental justice(s)}

Theorists of social justice in a development context, such as Amartya Sen, have contributed to refining our understanding of the notion of justice, as earlier theorized by John Rawls. They notably call for defining justice in the real world rather than pursuing an ideal, hence hypothetical and a-historical, notion of social justice. One of their most important contributions, at least in the context of this paper, is the articulation that justice is not only a matter of fair distribution of primary goods and services, such as utilities and resources, by just institutions but rather whether citizens have the capabilities to exert political choices on the use of these goods and services.

Notions of equity, equality and fairness are fundamental to any environmental decision-making but, when applied to the field of the environment, global justice theories may need to be adjusted to the context. Environmental decisionmaking is indeed largely influenced by the characteristics of the environment itself (Syme and Nancarrow, 2001) and the concept of environmental justice has evolved and been enriched over both historical and spatial scales. The concept of environmental justice developed from the 1970s onwards in industrialized countries, and particularly in the USA, in relation to civil rights movements, to address growing concerns of citizens regarding the distribution of environmental goods and bads due to an inequitable implementation of laws and policies (Davies, 2006;
Williams and Mawdsley, 2006). More recently, a growing body of literature on global environmental justice (for instance, Adger et al., 2001) has explored the skewed distribution of environmental burdens in some regions of the world (generally the global South) that result from activities taking place in (and benefiting) another region (e.g., the global North). Thematically, this literature has been mainly concerned with matters such as deforestation, desertification, biodiversity, and more recently climate change (Adger et al., 2001; Thomas and Twyman, 2005). Lastly, distinct environmental justice debates have emerged in the developing world (Martinez-Alier, 2004), especially in contexts characterized by: high social inequalities, a long-held tradition of social and political struggle, and a democratic space allowing for voicing demands such as in India, Brazil and South Africa (Blanchon et al., 2009). There, environmental justice acquires a particular resonance (for instance, Williams and Mawdsley, 2006) as the natural environment directly contributes to livelihoods in a considerable way and natural resource management interventions have an inherent development dimension. In the developing world, scholars' attention has shifted from the distribution of environmental hazards to the access to and use of natural resources that are of crucial importance in the rural contexts we study.

Across this diversity, environmental justice studies have highlighted two distinct yet interrelated aspects of justice. First, scholars have investigated the distributional consequences of environmental decisions and actions thus defining a "distributive justice" mostly concerned with outcomes and their distribution and closely linked to the notion of equity (Davies, 2006). Scholars highlight the spatial and social dimensions of distributive justice by showing that the environment is not unjust by itself. Indeed, it is through the relations that societies nurture with their environment that a particular situation is shaped and perceived as just or unjust. The result is some social groups being more vulnerable than others to extreme natural events or environmental inequities (for instance, Ribot, 2009). Second, scholars highlight that notions of legitimacy, identity and participation are central to the idea of justice. They call for recognizing citizens' opportunities and constraints in terms of participating in the decision-making process. They stress the procedural dimension of justice, which is mostly concerned with the processes through which outcomes are reached (Davies, 2006; Schlosberg, 2004). In this vein, it is argued that the "right processes will lead to the right outcomes, and that the right processes are those which are inclusive and participatory" (Davies 2006:711). When processes (procedural justice) fail to meet their intended outcomes (distributive justice), the reasons are to be found in the socio-political externalities in the context of implementation. Such duality echoes long-held concepts and debates in the field of development studies investigated in the next section. 


\subsection{Environmental justice and development processes}

\subsubsection{Power, capabilities and justice}

Scholars who study the political economy of natural resource management in developing countries have shown that despite the recent calls for decentralized and participatory natural resource management, policies around the world have paid little attention to procedural justice issues and have largely remained biased against the rural poor. Some policies have for example, been shown to be the outcomes of a negotiation process between international and national decision-makers without any consideration of the implication on poor resources users (Blaikie, 2006). In other cases, the design and implementation of policy has been restricted to specific groups or socio-economic classes, limiting the influence of local populations and thus primarily serving the interests of the group or class with the most political sway (Williams and Mawdsley, 2006). A focus on capitals and capabilities can enrich our understanding of justice concerns since capital that individuals or social groups draw on are not only seen as resources but also as means to achieve livelihood strategies and as ways for people to build their capability to change the dominant rules and power relationships governing how resources are controlled, distributed and transformed in society (Bebbington, 1999).

\subsubsection{Conceptualizing institutional formation to address justice concerns}

Environmental justice scholars have highlighted that governments in the developing world have relatively low capacity to address injustices. They argue that the implementation and enforcement of environmental and natural resource management policies and legislation has been weak and has failed to enhance distributive justice (Williams and Mawdsley, 2006). In order to overcome such pitfalls, policymakers and donors have increasingly turned towards institutional reforms. In the water sector, notable measures have included the creation of water user associations and the devolution of responsibilities (and, to a lesser extent, rights) to these new organizations (MeinzenDick, 2007). But these reforms have generally evolved towards over-formalized managerial approaches (Cleaver and Franks, 2005) that are heralded as true panaceas (for a critique, see Ostrom et al., 2007) and overlook procedural justice concerns. Alternatives to institutional panaceas centre on the notion of pluralism. Polycentricity, for example, highlights the existence of many centres of decision-making that are formally independent of each other (Ostrom et al., 1961). Polycentric systems are said to support sharing and shifting of power among multiple governing authorities at various scales and to favour institutional adaptation through mutual monitoring and learning (Neef, 2009; Ostrom, 2010). Similarly, the notion of institutional bricolage allows for conceptualizing how mechanisms for collective action and resource management are borrowed or reconstructed from existing overlapping and malleable sources (Cleaver and Franks, 2005).

\subsubsection{Discursive dimensions of environmental justice and development}

Scholars have explored the roles of discourses and narratives in the shaping of environment and development knowledge, policy, and practice (for instance, Hajer, 1995; Roe, 1994). Here, we consider discourses as both an expression of and a way to exercise power. First, discourses have been shown to use simplified storylines that mask the complexities of social-ecological systems, hence contributing to the promotion of blueprint interventions (Adger et al., 2001). Second, by shaping beliefs and perceptions, discourses frame the ways environmental problems and their solutions are debated. Third, by prescribing what is just or unjust, they influence policy outcomes by legitimizing certain institutions and power distribution schemes (Hajer, 1995). For instance, managerial and technical discourses tend to objectify the poor and depoliticize natural resource management, thereby failing to meet local demands and even sometimes reinforcing injustice. A discursive analysis of water interventions would contribute to unravelling their distributive and procedural justice dimensions.

\section{Planning and implementing water interventions: Two case studies}

\subsection{Context and methodology of the studies}

The context of the study is rural areas of the developing world, with a focus on two contrasting regions: West Bengal in northeast India and Burkina Faso and Ghana in sub-Saharan West Africa. We document two different interventions in the agricultural water sector. The first is the watershed development (WSD) programme, a major national Government-led initiative in rain-fed areas of India. Primarily designed to enhance water and soil conservation through small-scale and lowcost infrastructures, the WSD programme has been progressively extended to a comprehensive rural development programme integrating the objectives of productivity enhancement and livelihood improvement. The second is small reservoirs in sub-Saharan West Africa, which have been in high demand among local communities and popular on the agendas of national policymakers and international development partners since the major Sahel droughts of the 1970s. Small reservoirs were primarily designed to improve water access in mixed crop-livestock systems and are now described as an option to adapt to climate change and climate vagaries (Venot et al., 2012). 
The two studies approached the environmental justice dimension of water interventions from different angles and at different levels of analysis. In India, the study focused on micro-processes of access to water and on household capabilities, as observed in three communities in the district of Bankura, West Bengal in north-eastern India. In subSaharan West Africa, the study focused on community uses and perceptions of small reservoirs. Common to the two studies, however, is the investigation of: discourses, institutions and capabilities, and local claims and perceptions.

Data collection followed a multi-stage approach across multiple levels of governance in both studies. In India, a baseline census survey was conducted among all 190 households of three villages to assess the heterogeneity of water access, livelihood activities and farming systems. Quantitative and qualitative data on access to water, the institutions that govern access to capital, and the participation of households in planning and decisionmaking at the village level was then collected among a group of 69 representative households through: a questionnaire survey, participatory exercises (focus groups, transect walk, village mapping), and semi-structured interviews with households and key informants in the village (e.g., local elected representative, head of organizations, customary head of the village).

In Burkina Faso and Ghana, a rapid appraisal with extension agents of the Ministry of Agriculture yielded a comprehensive inventory of existing small reservoirs and detailed information on their design purpose and actual uses, their level of performance, and the institutional arrangements governing their management. We collected data for 249 small reservoirs in the south of Burkina Faso and 364 in the north of Ghana. We sought more in-depth information on the multiple uses and perceptions of small reservoirs by carrying out focus group discussions and semi-structured interviews with both male and female users of 32 randomly sampled reservoirs (rain-fed and livestock farmers, irrigators, and fishermen). Finally, we conducted key informant interviews with other community members (local elected representatives, customary authorities, representatives of Water User Associations and other local groups).

In both India and sub-Saharan West Africa, key informant interviews were also conducted with national and state policymakers, donors and technical development partners, government officials of line ministries (water resources, agriculture, irrigation and environment) to situate local level dynamics in the broader perspective of development and planning processes.

\subsection{Mediating environmental justice: Capital and capabilities}

A similar and dual consensus characterizes WSD projects in India and small reservoirs in sub-Saharan West Africa alike: these water interventions have tremendous potential but have not yet delivered on their promises. Such a narrative has provided the backdrop for endless technical and institutional quests that aim at solving past shortcomings but fall short of doing so. This, we argue, is because these repetitive attempts fail to articulate a concern for environmental justice. They notably overlook the heterogeneity of local situations and the fact that projects' outcomes are largely mediated by the capitals and capabilities of natural resources users.

Farmers in the Indian case study villages, for example, mostly belong to the Santal community, the largest indigenous group in Eastern India. They have traditionally cultivated a single monsoon paddy crop, and off-farm opportunities in the construction, coal mining and stone crushing sectors have supplemented agricultural revenues for several decades. Despite high annual average rainfall, access to water for agricultural purposes is one of their key concerns. Almost all farmers (99\%) surveyed reported suffering from water shortfalls for crop cultivation either seasonally or all year round. This is due to the unequal temporal distribution of rainfall $(80 \%$ of the rain is concentrated during the monsoon from June to September), the absence of canal infrastructures and the low groundwater potential of the area.

Access to water sources - either in the form of rainwater harvesting structures, dug wells, or rivulets and streams becomes critical for coping with dry spells during the monsoon season and engaging in dry season cultivation. In the case study villages, however, $30 \%$ of landowners do not have access to any water source and exclusively depend on rainfall for agriculture. Access to water appears to be highly skewed and dependant on multiple forms of capital (Clement et al., 2011). For instance, access to rivulets and streams is de facto constrained by access to physical capital (a diesel pump) or financial capital to rent a pump and buy diesel. Access to pumps can also depend on social capital. In one of the villages, for example, the pumpset provided by the government was captured by a few influential households.

Natural inequities to access water can be reinforced or lessened by social processes, among which are external development interventions. In one of the case study villages for example, the panchayat samithi (block level local elected body) initiated the construction of a bund across a rivulet, by resorting to community work, to retain water during the dry season for vegetable cultivation. Villagers voluntarily repeated the work the following years. The panchayat samithi also gave a pump to be shared by the 17 households of the community. A few years later, the pump broke down. Members of one household decided to pay for the repairs and subsequently appropriated the pump. The new de facto owner restricted access to the pump to three families with whom he had a tight kinship. The following year, most villagers refused to participate in the construction of the bund on the ground that they would 
not benefit from the pump. Inequities in pump access, determined by social processes, ultimately impeded collective action even though the rivulet was a common pool resource that could be accessed by anybody from the village.

As far as WSD programmes are concerned, the State response to low water availability focused on the construction of small scale water infrastructures. Specific interventions were chosen following a technical and socioeconomic survey led by a non-governmental organization (NGO) which had worked for several years in the area. The NGO led several meetings during which communities were invited to choose the interventions and where in the villages they would be implemented. Across the three villages $65 \%$ of all households participated in these meetings. The initial institutional arrangements for the WSD projects to be successful seemed to be assembled: interventions meeting farmers' demand, a committed NGO sensitive to equity issues who had established a long-term trust relationship with the villagers, and a relatively high participation of the latter. However, four years later, bitter memories persist among villagers regarding these interventions. Among the people interviewed and surveyed, 44\% reported to have benefited from WSD. For two thirds of those, the only benefit they mentioned was in the form of paid labour for projectrelated works. Further, due to unexpected budget cuts, most of the small scale water infrastructures that had been collectively identified were left uncompleted. There was no mechanism for the communities to hold policymakers and the project implementation agency accountable, as is commonly observed in many development interventions. These uncompleted structures act as further deterrent for farmers to trust the government as, to them, "either the government completes the work, or they don't commit. A well half dug is not good, we prefer no well" (focus group discussion, January 2010).

Concerning small reservoirs in sub-Saharan West Africa, the debates on their performance clearly overlook local heterogeneity and communities' perceptions and priorities. Results of a rapid appraisal (613 small reservoirs sites) indicate that agricultural extension agents consider nearly 50 per cent of all small reservoirs in the study region as poorly performing (Venot et al., 2012). Agricultural extension agents emphasized criteria such as the extent of the irrigated area, the number of irrigators, the water and agricultural productivity and the physical condition of the infrastructure. They assessed the performance of small reservoirs through an engineering lens and in line with the objective of irrigation development.

A different picture emerges when investigating local users' perceptions of performance. Detailed studies were conducted for 32 small reservoirs. In all cases, the local population expressed a level of satisfaction similar or higher than the extension agents (Venot et al., 2012). Like extension agents, local users pointed to poor technical and
Table 1. Multiple benefits of small reservoirs in northern Ghana

\begin{tabular}{lc}
\hline Three highest ranked benefits per category & Frequency (\%) \\
\hline Basic benefits & 58 \\
Improved food security & 58 \\
Bathing & 55 \\
Improved access to domestic water (drinking/cooking) & 45 \\
Social benefits & 41 \\
Enhance women's position within the household & 40 \\
Recreation & \\
Reduced migration (for domestic/livestock watering) & 70 \\
Economic benefits & 58 \\
Improved water availability for livestock & \\
Enhanced productive activities (fisheries, brick making, & 49 \\
$\quad$ irrigation) & \\
Improved income from productive activities & 38 \\
Environmental benefits & 38 \\
Limiting floods & 29 \\
Improved greenness and increase bio-diversity & \\
Improved weather conditions (freshness) &
\end{tabular}

Note: Results are based on 338 interviews with users (livestock farmers; men, women and young agriculturalists, and fishermen) of 16 small reservoirs located in the north of Ghana.

Source: Venot et al. ( 2012).

managerial performance. They however showed a higher level of satisfaction regarding the benefits they derived and the equity aspects of small reservoirs — thus illustrating their concern for distributive justice. Table 1 presents the results of a free listing exercise during which local users of small reservoirs were asked to identify the three main benefits they derived from small reservoirs. Some benefits are clearly linked to irrigation development (improved food security, enhanced productive activities, improved income) but small reservoirs are also said to improve water availability for livestock and domestic uses, thus limiting migration and playing a positive role on women's position within their household because they spend less time fetching water and can spend more time on other activities.

The surveys revealed that small-scale water users and most marginal groups (the poor, youth, women, and fishermen) tend to derive and value basic benefits (such as bathing, small handicraft activities and improved domestic water supply) more than livestock farmers and agriculturalists. This is because they do not have the capital and capabilities to invest in so-called productive activities. They also face difficulties in reaping direct benefits when intensive cultivation becomes the main goal, and they give lower satisfaction scores when irrigation takes place since irrigators tend to corner water resources. The notion of distributive justice reminds us of the need and difficulties of coordinating multiple users and social groups around a common pool resource, especially when specific organizational set-ups are promoted from the outside in a broader discursive context focusing on efficiency and productivity. 


\subsection{Promoting procedural justice: Towards a pluralist approach to institutional formation}

Problem-diagnosis exercises and performance assessments are seen as useful tools to aid water interventions to deliver on their promises. Comparisons of so-called successful and unsuccessful projects have long formed the basis for identifying flaws in design and implementation. For WSD programmes in India and small reservoirs in sub-Saharan West Africa alike, most of the identified shortcomings have been attributed to technical, institutional or managerial issues: a narrow focus on soil and water conservation (India) or irrigation development (West Africa) with limited attention to livelihood improvement; the inadequacy of the size of the watershed (India) or the water available in the small reservoir (West Africa); rigid rules, the timeline of and funds allocated to projects, the lack of capacity of local communities, and the lack of professionalism and skills of implementing agencies (both India and West Africa).

Such diagnoses have informed repeated policy revisions and institutional reforms. The WSD guidelines of 2008 are, for example, the 9th set of guidelines since 1995, when the Government of India initiated the first nation-wide WSD programme as a way to upscale and harmonize scattered past efforts in the rain-fed areas of India. In sub-Saharan West Africa, and since the mid-1990s, development partners and national governments have repeatedly called for devolving decision-making over small reservoir resources to Water User Associations.

Following a growing disenchantment over past reforms, scholars have debated whether institutional refinement is necessary to overcome poor policy outcomes, thus polarizing the debate between the relevance of improving policy design versus improving policy implementation (see, for instance, Reddy, 2006 in the Indian case). This debate, we argue, is unlikely to provide the conditions for a decisive breakthrough, since it does not allow for investigating the link between current institutional approaches and environmental justice concerns, either at the implementation or design stage of water interventions. Investigating this link is what this section entails to do through two case studies.

WSD interventions in Bankura District have followed what is commonly held as being a participatory process. Villagers were invited to decide on the interventions to be implemented but could only choose within a limited set of interventions that had been pre-defined by distant policymakers or the implementing agency. In one of the villages studied, for instance, the only intervention consisted of planting mango orchards. The trees proved to be ill-adapted to the local environment and few survived despite farmers' care. Participation in the decision-making process was limited to agreeing to what the NGO was proposing. As put by one villager: "The NGO decided to plant mango trees. They told Mahadev [the village resource person], who told the villagers. Then the villagers decided to plant mango trees" (interview, February 2009). In most villages, the suite of options proposed consisted mostly of infrastructures that tended to benefit relatively large landholders - those who have sufficient land area to build rainwater harvesting structures. Possible discrepancies between local needs and state interventions were commonly dismissed by public planners and implementers who consider that "there is a scheme for every need" (Interview, high level district government official, May 2009). Further, even if villagers have more room to choose among different options, they or their local elected representatives do not have control over the rules of implementation - for instance, on the allocation of funds.

In this respect, WSD programmes have to be understood within the broader decentralization framework of India, in which the devolution of political, administrative and fiscal authority to panchayati raj institutions has greatly differed among Indian states and remains incomplete in most (Planning Commission of India, 2010). The WSD guidelines propose that suitable institutional arrangements will be established through the framework of panchayati raj institutions (Government of India, 2008). The election of a watershed committee in the gram sabha meeting is meant to ensure equity. Yet the gram sabha and watershed committees have commonly suffered from a lack of representation and influence of women and lower classes and castes (Reddy et al., 2009). The guidelines barely mention the processes that are meant to ensure the accountability of the Watershed Committee to the community, despite evidence of asset capture by local elites during project implementation (Baviskar, 2004). The project implementing agencies, especially state line departments, are also little accountable to the local population. They have little incentive to ensure equity, as their activities and performance are not evaluated against this criterion, nor are WSD outcomes.

Ensuring actual participation of local users in decisionmaking over small reservoirs is riddled with very similar challenges to those observed in the case of WSD programmes in India. The current blueprint for small-scale irrigation development is one of participatory, communityled projects. In many instances, this has been equated to the establishment of Water User Associations (WUA) by development partners and national Governments. By overseeing the maintenance and management of small reservoirs, WUAs would enhance their performance and guarantee their long-term sustainability. Development practitioners partly determine the performance and success of small-reservoir projects by the numbers of WUA that are set up alongside construction or rehabilitation works. Yet, in most cases WUAs remain promoted by outsiders, on the basis of (inter)national policy reforms, rather than

\footnotetext{
The gram sabha brings together voters from the administrative area of the gram panchayat (village level).
}

(C) 2012 The Authors. Natural Resources Forum (C) 2012 United Nations 

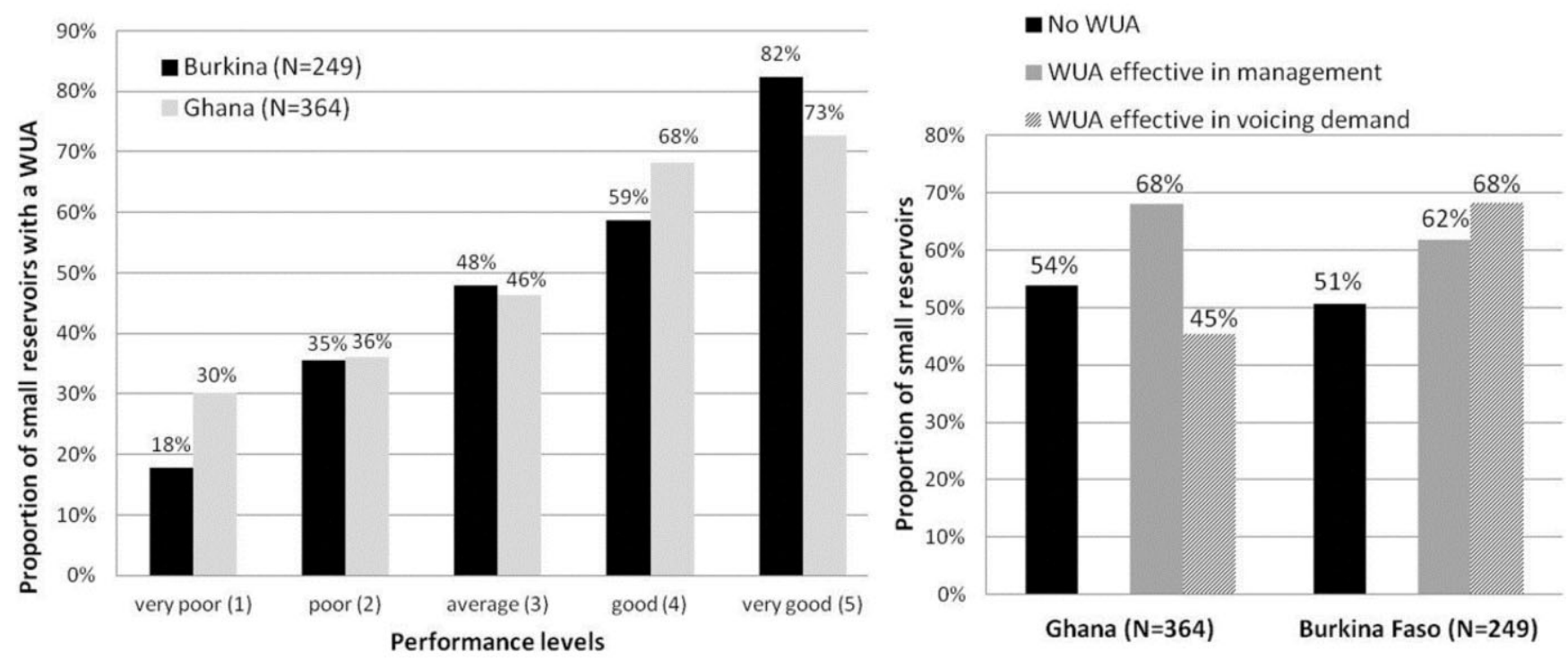

Figure 1. Linking Water User Associations and performance of small reservoirs.

Source: Authors' elaboration.

being the expression of a collective decision-making process emerging from the community. ${ }^{2}$

Extension agents support the view that the presence of a WUA is positively correlated to the good performance of small reservoirs (the proportion of WUAs among well performing reservoirs is higher than among poor performing ones; Fig. 1, left panel). On the other hand, in absolute terms and among the good performing reservoirs, there are as many small reservoirs with WUAs as there are without them. This implies that the presence of a WUA is neither a pre-requisite nor a guarantee for good performance, as often assumed by development projects that consider the existence of a user organization as a precondition to further intervention. Further, Fig. 1 (right panel) shows that, on average, the same extension agents consider that one to two thirds of the existing WUAs are effective in terms of small reservoir management and as an arena to express and voice the concerns of local users. Finally, among the 32 small reservoirs detailed case studies, there was no clear correlation between the level of satisfaction of local users and the presence or absence of a WUA. WUAs, when existing, remained mostly dormant. Members did not meet and no minor maintenance activities were conducted.

WUAs have acquired a positive discursive resonance that contributes to framing the perception of agricultural extension agents. Rather than creating the conditions for collective action and sustainable management of infrastructure, the WUA has become an institutional fix. WUAs are considered inherently good and an indicator of

\footnotetext{
${ }^{2}$ See Meinzen-Dick (2007) for a critical review of Water User Associations' role in irrigation management.
}

good performance, regardless of the processes followed for their establishment and of their outcomes.

We suggest here that in their insistence to establish a "one-mode-fits-all" (the WUA) as a panacea, small reservoir projects give little attention to procedural justice. This is not to say that WUAs do not have a role to play, but major shortcomings still remain for them to fully contribute to the sustainable governance of small reservoirs. Structurally and in regard to distributive justice, WUAs appear to convey the concerns of only some segments of the population. Though multiple uses are a characteristic of all small reservoirs surveyed (as for most water infrastructure; van Koppen et al., 2009) and can amount to significant water consumption, $85 \%$ of the existing WUA were centred on downstream irrigators who were often little dynamic. Less than half the WUAs accounted for other small-scale water users or women - who rarely held any executive positions. Involving water users who operate on a more individual basis (upstream irrigators) or use small reservoir water with a less clear pattern (livestock farmers who often belong to different ethnic groups and are more mobile) or to a lesser extent (fishermen, brick makers, craft men and women) than irrigators would require devoting more time to institution-building. This is often impossible given the tight schedule imposed by project design. In procedural terms, and as observed in the India case, development partners still consider local actors as recipients or beneficiaries rather than participants with agency in a community-led project. Or, when stating that "the failure to complete the appraisal target [was] partly due to the time wasted 'sensitizing' the communities" (IFAD, 2009:291), project workers and designers show how little value they give to interacting with communities and considering local priorities. 
Table 2. Repartition of responsibilities regarding small reservoirs management (percentage)

\begin{tabular}{|c|c|c|c|c|c|c|c|c|c|}
\hline & $\begin{array}{c}\text { Line } \\
\text { ministries }\end{array}$ & Donors & Contractors & $\begin{array}{c}\text { Local } \\
\text { government }\end{array}$ & $\begin{array}{l}\text { Traditional } \\
\text { authorities }\end{array}$ & $\begin{array}{c}\text { User } \\
\text { committees/ } \\
\text { WUA }\end{array}$ & Community & Farmers & Others \\
\hline $\begin{array}{l}\text { Identified as the most important } \\
\text { decision-maker }\end{array}$ & 5 & & & 12 & 23 & 35 & 22 & 2 & 1 \\
\hline \multicolumn{10}{|l|}{$\begin{array}{l}\text { Identified has having some } \\
\text { responsibility regarding: }\end{array}$} \\
\hline Sitting/Design/Construction & 39 & 5 & 30 & 6 & 3 & 2 & 4 & 2 & 3 \\
\hline Major maintenance & 41 & 13 & 6 & 18 & 2 & 8 & 4 & 3 & 3 \\
\hline Minor maintenance & 4 & & & 5 & 4 & 34 & 46 & 6 & 3 \\
\hline Setting of management rules & 4 & & & 4 & 23 & 40 & 23 & 6 & 2 \\
\hline Implementing/monitoring rules & 5 & & & 4 & 12 & 47 & 24 & 6 & 4 \\
\hline Relation with other actors & 14 & 1 & & 10 & 11 & 39 & 19 & 3 & 5 \\
\hline Conflict resolution & 6 & & & 9 & 60 & 22 & 13 & 1 & 2 \\
\hline Environmental protection & 9 & & & 4 & 9 & 33 & 34 & 10 & 3 \\
\hline Extension role & 69 & 2 & & 2 & 2 & 5 & 2 & & 6 \\
\hline Agricultural practices and marketing & 12 & & & 1 & 4 & 12 & 13 & 49 & 6 \\
\hline
\end{tabular}

Note: Percentages indicate the frequency with which extension agents identified specific actors in relation to specific tasks. Extension agents identified several actors as having some sort of responsibilities for each specific task hence the sum of percentages exceeds 1 for any specific tasks (lines). Data was collected for 197 and 321 small reservoirs in Burkina Faso and Ghana, respectively.

Source: Authors' elaboration.

Finally, the current approach to the establishment of WUAs largely overlooks the pluralist nature of common property resources management even though agricultural extension agents themselves identified no fewer than seven types of actors contributing to the management of small reservoirs. These actors, organizations and institutions assume different and complementary roles along the project cycle (Table 2).

Extension agents consider the management of small reservoirs to be pluralistic, as clearly indicated in their answers to the question "who is the main decision-maker regarding the small reservoirs located in the community?" In $60 \%$ of the cases, extension agents singled out one type of actor but also mentioned that others had a role to play; only $40 \%$ of the extension agents identified a single actor when answering to the question. Water committees (e.g., WUAs) were identified as the main decision-making body over small reservoirs in about one third of the cases (alone or with others), and their main tasks were considered to be minor maintenance and daily management (Table 2) once small reservoirs are built/rehabilitated. Though they often exist prior to construction works, WUAs and water users appear to have little say in the early stages of the projects when issues such as design and siting are discussed (these remain the remit of line ministries and contractors; Table 2). Line ministries and government agencies are rarely identified as the main decision-makers $(5 \%)$ but their role in procurement and construction processes, as well as in supporting farmers (extension, marketing) is seen as crucial (Table 2). The importance conferred to traditional authorities and the community as a whole, identified as the main decision-makers in $23 \%$ and $22 \%$ of the cases, respectively, is another example of institutional bricolage at play. WUAs often count (officially or not) a member of the traditional authorities among their executive members hence providing for a continuous negotiation between so-called "traditional" and "modern" institutions. This can lend power to the WUA when it comes to settling disputes, resolving conflicts, maintaining social cohesion, and dealing with land allocation and redistribution issues (Table 2). But this might lead to elites cornering responsibilities and associated benefits. Local government institutions are involved, but in a limited way and mostly in relation to the very political issue of site selection.

\subsection{A concern for environmental justice: Discourses and realities}

Discourses that underpin and legitimize specific water interventions play a significant role in whether the latter eventually address environmental justice concerns. Both WSD programmes in India and small reservoirs in West Africa appear to be grounded in a narrative that stresses the need for agriculture intensification and diversification in rural rain-fed areas.

In India, the increased importance given to the WSD approach from the mid-1990s onwards arose from two parallel growing concerns and narratives (Shah, 2006): one was the steady decline in per capita grain production that was attributed to a fall in agricultural investments, and the second was the limited potential to expand irrigated areas. This contributed to the fact that WSD programmes focused on so-called productive investments. Sub-Saharan Africa, in contrast, is described as having the lowest agricultural productivity in the world and as having witnessed an increase in the numbers of poor people while the potential 


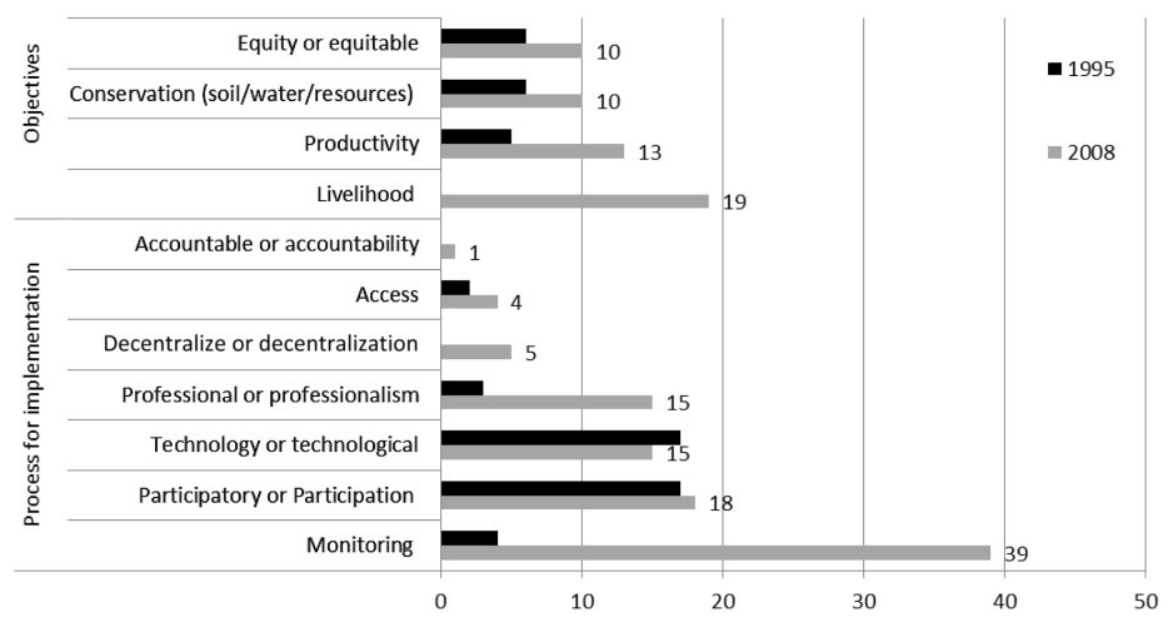

Figure 2. Occurrence of key terms in 1995 and 2008 WSD Guidelines. Source: Authors' elaboration.

of its ample water resources remains to be harnessed, notably though irrigation (FAO, 2008). The New Partnership for Africa's Development (NEPAD) identifies water management and irrigation development as one of the "areas for primary action" of its Comprehensive Africa Agriculture Development Programme (CAADP) and prioritizes "the identification and preparation of investments to support small-scale irrigation" (NEPAD, 2003:28). Though they can also be cast as "traditional systems" exemplifying the ideals of bottom up development or as small-scale infrastructures that make them compatible with calls for participation (see the above section), small reservoirs appear to be part and parcel of a broader paradigm geared towards the efficient and productive use of land and water resources rather than at enhancing environmental justice.

In India, the notion of justice seems to be incorporated in the 2008 Guidelines. Three out of the seven guiding principles of the guidelines are inclusive of distributive or procedural justice concerns: (1) equity and gender sensitivity; (2) decentralization; and (3) community participation. Yet, a closer look at the occurrence of key terms in two sets of WSD guidelines (Fig. 2) suggests that WSD projects are still framed as apolitical and technical interventions (Baviskar, 2004; Chhotray 2007). For instance, the WSD guidelines remain overtly focused on participation but hardly mention accountability (Fig. 2). They also give a high importance to technology and to managerial processes such as "monitoring" and the increase of "professionalism" (Fig. 2). This is not to deny the importance of such management practices, but development scholars have earlier observed that managerial processes tend to be geared towards efficiency at the cost of distributive and procedural justice concerns (Mosse, 2005).

The managerial drive suggested by this rough text analysis was corroborated by interviews with officers from the government and project implementing agencies. For instance, the drafting of the Detailed Project Reports (DPR), which collate biophysical and social information and present local people's visions and plans for the development of their watershed, was aimed at building a long-term relationship between communities and the project implementing agency. But the Department of Land Resources of the central government sees the writing of DPR as a merely bureaucratic and scientific exercise. As expressed during an interview, "[the Department] just checks that the DPR is prepared as per the guidelines. If it conforms, then it releases the funds" (interview, September 2011). Consequently, policymakers of the Department are pushing the States to submit DPRs faster. For them, indeed, "the DPR should not take more than a week" (interview, September 2011). In this context, procedural justice is overlooked as project implementing agencies spend little time to elaborate the DPRs and merely "fill up the boxes" by proposing similar technical fixes, regardless of the situation on the ground.

At the local level, development discourses and practices were also found to pay scant attention to distributive justice concerns. According to the "Additional District Magistrate" of Bankura District, the key objective of the government in the region is "to utilize local resources". One of the aims of major rural development programmes is "to create as many sources of water as possible" (interview, September 2009). Similar to extension agents who, in West Africa, assessed small reservoir performance in line with the extent of irrigation taking place, officers from the agricultural department equated the success of agriculture with high crop productivity. Narrowly defined objectives of increasing productivity have often clashed with equity concerns (Das, 2002), which appeared to be of prime importance for farmers in both the regions we studied. 


\section{Discussion}

The case studies in northeast India and sub-Saharan West Africa highlight the intricate relationships between development and environmental justice concerns that characterize the planning and implementation of water interventions in the developing world.

First, the two case studies illustrate that the capitals and capabilities of local communities emerge as key mediating factors to achieve distributive justice. Financial, physical and social capital, power relationships, and the capabilities that local users have to influence these, determine how benefits of development interventions are distributed among and within communities. In India, water interventions such as WSD programmes have long neglected the social relationships that shape the capabilities to access water; they de facto favoured the local elite. In sub-Saharan West Africa, small-scale water users do not necessarily have the capabilities to engage in agricultural intensification, which is the main reason why small reservoir projects are promoted. Here too, the local elite tend to benefit greatly from water interventions. Further, both in India and West Africa, water interventions have claimed achieving procedural justice by involving people in decision-making through participatory approaches. However, development studies remind us that procedural justice is about giving citizens the opportunity and capacity to develop their capabilities rather than to choose among different types of capital proposed by external actors. In India, as in sub-Saharan Africa, current forms of decentralization and development planning limit the extent to which local populations are involved in decision-making. Natural resource users and their elected representatives do participate in development projects, but seldom are they their initiators. Local actors can choose from a menu of options but are rarely offered the opportunity to think, consult experts and decide. Interventions mostly depend on the decisions of a series of bureaucrats at multiple administrative levels, who are seldom accountable to the targeted population. Despite the rhetoric, local actors are still conceived as passive recipients of externally defined water interventions, rather than agents of their own development.

Second, the case studies illustrate that water interventions embed a narrow vision of common pool resources and institutional formation. Attempts at institution-building overlook the social relationships through which participation, authority, legitimacy and accountability are continuously negotiated among multiple actors. Water interventions are largely depoliticized; they are cast as technical interventions which require formalized managerial structures to be successful. In India, WSD programmes are examples of state-led initiatives that herald the notion of participation as a priority but without devolving much decision-making power to local communities. In sub-Saharan West Africa, WUAs and institutional capacity-building have become key components of all small scale irrigation projects, but the approach adopted remains at loggerheads with the pluralist character of environmental decision-making. In both cases, the rhetoric and over managerial approaches fall short of meeting procedural justice concerns.

Finally, the two case studies clearly show a tension between calls for equity, which are meant to address local concerns of well-being and distributive justice, and the global narrative on "achieving the potential" and increasing agricultural productivity, which drives rural development in general and water interventions in particular. The productivity narrative induces a technical or at best a socialengineering approach geared towards an efficient use of resources. But the concept of efficiency is defined by actors who do not use the resources and whose perception might be at odds with the concerns of the local population. It often results in the development of structures that mostly benefit the better-off, because the farming systems or livelihoods activities of the poor are generally judged unproductive. In India, the pursuit of productivity has taken place at the expense of distributive justice, as many WSD projects have supported "productive" tree plantations on "unproductive" common grazing land, depriving landless livestock owners (Calder etal., 2008). The shift induced by WSD interventions, from communal use of water in tanks to private groundwater use, has also negatively impacted the poor as groundwater access is determined by land ownership and is governed by markets. In the case of small reservoirs in West Africa, and despite the importance of multiple use systems, this focus on efficiency and productivity is clearly highlighted by the priority given by development agencies and governments alike to irrigation over other practices such as livestock watering, fishing, small handicraft, and domestic uses that are generally considered as less productive, yet, are crucial to rural livelihoods, especially for the poor, youth and women.

\section{Conclusion}

The notion of environmental justice acquires a particular resonance in the context of developing countries where the contribution of the natural environment to livelihoods is significant. This calls for creative analytical frameworks to shed light on its pluralistic character.

This paper uses the vocabulary for political action that is embedded in the notion of environmental justice and reinforces the analytical dimension of the latter by using notions of capabilities, institutions and discourses, which have long informed critical development studies. We discuss two water interventions in the developing world, namely, watershed development programmes in India and small reservoirs in sub-Saharan West Africa.

This approach proves useful to understand the multiple claims and perceptions that water interventions entail, or in 
other words, to make their political dimension apparent. As a vocabulary for political action, environmental justice provides water planners and environmental decisionmakers in the developing world with a policy principle regarding common pool resource management. Natural resources projects and policies should evolve from the current situation, whereby participation remains externally triggered from the top, to one where citizens would have genuine opportunities for decision-making (procedural justice) over the distribution of environmental and social costs and benefits (distributive justice). Syme and Nancarrow (2001) stress that there can be no normative evaluations of the adequacy of policies in justice terms, just a series of perceptions depending on one's point of view. It is then important that such an empirical shift is informed by a constructive theoretical dialogue between environmental justice theory and debates in the field of development studies.

For environmental justice scholars and advocates, critical development studies offer the scope to address procedural justice concerns by better understanding the dynamics of institutions, participation and decentralization that have dominated the rural development agenda for the last 20 years. Discourse analysis allows for identifying possible impediments to the achievement of environmental justice by exploring, for instance, how issues are framed and how the role of various actors is perceived. In turn, for critical development studies scholars, environmental justice, in its procedural and distributive dimensions, is a reminder that communities are not passive recipients of institutional reforms, or victims of their environment or of hegemonic discourses. The example of small reservoirs in sub-Saharan West Africa clearly shows that water interventions are spun in various ways by different actors. The boundaries between the global and the local tend to disappear as the local (rural populations and local decision-makers) appropriates global narratives on participation and performance that appeal to national and global actors. In turn, this gives the latter a justification for pursuing the construction or rehabilitation of small reservoirs, which are, however, transformed according to local priorities that are often at loggerheads with the discourses used to justify their construction. In short, the local meets its own objective of justice and development through global discourses; the "environmentalism of the poor" (Martinez-Alier, 2004) and the global environmental justice narratives meet each other. By better understanding this articulation between metanarratives and local concerns, it would then be possible to go past a linear vision of development and societal change.

\section{Acknowledgements}

At the time of the research, the first author was affiliated with the International Water Management Institute (IWMI) in West Africa. An earlier version of this paper was presented at the conference on "Global Environmental Justice: Towards a New Agenda" held in Norwich, UK on 2-3 July 2010. We are thankful to the organizers and participants of the workshop, to Mark Giordano and to five anonymous reviewers whose comments and feedback contributed to improve the quality of the paper.

\section{References}

Adger, W.N., Benjaminsen, T.A., Brown, K., Svarstad, H., 2001. A political ecology of environmental discourses. Development and Change, 32(4): 681-715.

Agyeman, J., Evans, B. 2004. Just sustainability: The emerging discourse of environmental justice in Britain? The Geographical Journal, 170(2): $155-164$.

Baviskar, A., 2004. Between micro-politics and administrative imperatives: Decentralisation and the watershed mission in Madhya Pradesh, India. European Journal of Development Research, 16(1): 26-40.

Bebbington, A., 1999. Capitals and capabilities: A framework for analyzing peasant viability, rural livelihoods and poverty. World Development, 27(12): 2021-2044.

Blaikie, P.M., 2006. Is small really beautiful? Community-based natural resource management in Malawi and Botswana. World Development, 34(11): 1942-1957.

Blanchon, D., Moreau, S., Veyret, Y., 2009. Comprendre et construire la justice environnementale. Les Annales de Géographie, 2009(1-2): $35-60$.

Calder, I.R., Gosain, A., Rama Mohan Rao, M.H., Batchelor, C., Snehalata, M., Bishop, E., 2008. Watershed development in India biophysical and societal impacts. Environment, Development and Sustainability, 10(4): 537-557.

Chhotray, V., 2007. The "anti-politics machine" in India: Depoliticization through local institution building for participatory watershed development. Journal of Development Studies, 43(6): 1037-1056.

Cleaver, F., Franks, T., 2005. How institutions elude design: River basin management and sustainable livelihoods. BCID Research Paper 12. Bradford: University of Bradford.

Clement, F., Ishaq S., Haileslassie, A., Blummel, M., Murty, M.V.R., Samad, M., Dey, S., Das, H., Khan, M.A., 2011. Enhancing water productivity for poverty alleviation: Role of capitals and institutions in the Ganga Basin. Experimental Agriculture, 47(S1): 133-151.

Cornwall, A., Brock, K., 2005. What do buzzwords do for development policy? A critical look at participation, empowerment and poverty reduction. Third World Quarterly, 26(7): 1043-1060.

Das, R.J., 2002. The green revolution and poverty: A theoretical and empirical examination of the relation between technology and society. Geoforum, 33(1): 55-72.

Davies, A.R. 2006. Environmental justice as subtext or omission: Examining discourses of anti-incineration campaigning in Ireland. Geoforum, 37(5): 708-724.

FAO (Food and Agriculture Organisation), 2008. Water and the Rural Poor: Interventions for Improving Livelihoods in Sub-Saharan Africa. FAO, Rome.

Government of India (GoI), 2008. Common Guidelines on Watershed Development Projects. GoI, New Delhi.

Hajer, M.J., 1995. The Politics of Environmental Discourse: Ecological Modernization and the Policy Process. Oxford University Press, Oxford.

IFAD, 2009. The Republic of Ghana Northern Rural Growth Programme (NRGP) - design document appraisal: Volume 2, Working Papers 1-5. IFAD, Rome.

Lund, C., 2010. Approaching development: An opiniated review. Progress in Development Studies, 10(1): 19-34. 
Martinez-Alier, J., 2004. The Environmentalism of the Poor: A Study of Ecological Conflicts and Valuation. Edward Elgar, Cheltenham.

Meinzen-Dick, R., 2007. Beyond panaceas in water institutions. Proceedings of the National Academy of Science in the United States of America, 104(39): 15200-15205.

Mosse, D., 2005. Cultivating Development. An Ethnography of Aid Policy and Practice. Pluto Press, London.

Neef, A., 2009. Transforming rural water governance: towards deliberative and polycentric models? Water Alternatives, 2(1): 53-60.

NEPAD, 2003. Comprehensive Africa Agriculture Development Program. NEPAD, Johannesburg.

Ostrom, E., 2010. Polycentric systems for coping with collective action and global environmental change. Global Environmental Change, 20(4): 550-557

Ostrom, E., Janssen, M.A., Anderies, J.M., 2007. Going beyond panaceas. Proceedings of the National Academy for Sciences, 104(39): 1517615178.

Ostrom, V., Tiebout, C.M., Warren, R., 1961. The organization of government in metropolitan areas: A theoretical inquiry. American Political Science Review, 55(4): 831-842.

Planning Commission of India, 2010. Mid-term Appraisal of the Eleventh Five Year Plan 2007-2012. Oxford University Press, New Delhi.

Reddy, V.R., 2006. "Getting the implementation right". Can the proposed watershed guidelines help? Economic and Political Weekly, 41(40): 4292-4295.

Reddy, V.R., Reddy, M.G., Soussan, J. 2009. Political Economy of Watershed Management. Policies, Institutions, Implementation and Livelihoods. Rawat Publications, Hyderabad.
Ribot, J.C., 2009. Vulnerability does not fall from the sky. Towards multi-scale pro-poor climate policy. In: Mearns, R., Norton, A. (Eds.), Social Dimensions of Climate Change: Equity and Vulnerability in a Warming World. World Bank, Washington, DC.

Roe, E., 1994. Narrative Policy Analysis, Theory and Practice. Duke University Press, Durham, NC.

Schlosberg, D., 2004. Reconceiving environmental justice: Global movements and political theories. Environmental Politics, 13(3): $517-540$.

Shah, M., 2006. Towards reform. Economic and Political Weekly, 4(26-27): 2981-2984.

Syme, G.J., Nancarrow, B.E., 2001. Social justice and environmental management: An introduction. Social Justice Research 14(4): 343-347.

Thomas, D.S.G., Twyman, C., 2005. Equity and justice in climate change adaptation amongst natural-resource-dependent societies. Global Environmental Change, 15(2): 115-124.

Van Koppen, B., Smits, S., Moriarty, P., Penning de Vries, F., Mikhail, M., Boelee, E., 2009. Climbing the Water Ladder: Multiple-use Water Services for Poverty Reduction. IRC: The Hague.

Venot, J.P., de Fraiture, C., Nti-Acheampong, E., 2012. Revisiting dominant notions: A review of costs, performance and institutions of small reservoirs in sub-Saharan Africa. IWMI Research Report No. 144. IWMI, Colombo.

Williams, G., Mawdsley, E., 2006. Postcolonial environmental justice: Government and governance in India. Geoforum, 37(5): 660-670. 